\title{
PELATIHAN ANALISIS TRANSAKSIONAL (AT) UNTUK PENINGKATAN KEMAMPUAN KOMUNIKASI INTERPERSONAL PADA PERAWAT POLI EKSEKUTIF DI PAVILIUN NUSA INDAH RSUD DR ADHYATMA MPH PROVINSI JAWA TENGAH
}

\author{
Destri Luh Sita Dewi ${ }^{1}$, Rahma Widyana ${ }^{2}$, Sriningsih ${ }^{3}$ \\ ${ }^{123}$ Fakultas Psikologi Universitas Mercu Buana Yogyakarta \\ 1destri@gmail.com \\ 2umifaqih4@yahoo.com \\ ${ }^{3}$ sri_umby@yahoo.com
}

\begin{abstract}
Abstrak
Penelitian ini bertujuan untuk mengetahui pengaruh pelatihan analisis transaksional (AT) untuk peningkatan kemampuan komunikasi interpersonal pada perawat poli eksekutif Nusa Indah RSUD Dr. Adhyatma, Provinsi Jawa Tengah. Hipotesis yang diajukan penelitian ini adalah ada perbedaan kemampuan komunikasi interpersonal antara subjek yang mendapatkan pelatihan AT dengan subjek yang tidak mendapatkan pelatihan AT, ada perbedaan skor kemampuan komunikasi interpersonal pada kelompok eksperimen sebelum dan sesudah diberikan pelatihan AT. Subjek penelitian ini sebanyak 10 orang perawat poli eksekutif Nusa Indah RSUD Dr. Adhyatma, Provinsi Jawa Tengah. Subjek dibagi menjadi 2 kelompok, yaitu 5 orang subjek sebagai kelompok eksperimen, dan 5 orang subjek sebagai kelompok kontrol. Penempatan subjek dalam kelompok dilakukan secara random. Desain yang digunakan dalam penelitian ini adalah randomized pretest-posttest control group design. Pengukuran dilakukan dengan pengukuran pretest, post-test, dan follow-up menggunakan skala Kemampuan Komunikasi Interpersonal. Metode analisis yang digunakan adalah analisis non parametrik (Mann-Whitney dan Uji Wilcoxon). Hasil uji hipotesis menghasilkan nilai $\mathrm{Z}=-2,032(\mathrm{p}<0,01)$, artinya ada perbedaan kemampuan komunikasi interpersonal antara kelompok eksperimen dan kelompok kontrol. Selisih rerata skor kemampuan komunikasi interpersonal kelompok eksperimen $(69,4)$ lebih besar daripada kelompok kontrol $(-5,8)$, sehingga hipotesis penelitian ini diterima. Pada kelompok eksperimen menunjukkan ada perbedaan signifikan antara sebelum dan sesudah pelatihan $(\mathrm{Z}=-2,023 ; \mathrm{P}<0,01)$, dengan peningkatan rerata skor sebesar 71,6 sehingga hipotesis juga diterima.
\end{abstract}

Kata kunci: analisis transaksional, kemampuan komunikasi interpersonal

\section{TRANSACTIONAL ANALYSIS TRAINING (TA) TO COMMUNICATION SKILLS NURSE IN PAVILIUN EXECUTIVE NUSA INDAH HOSPITAL DR ADHYATMA MPH CENTRAL OF JAVA}

\author{
Destri Luh Sita Dewi ${ }^{1}$, Rahma Widyana ${ }^{2}$, Sriningsih $^{3}$
}

\begin{abstract}
This research is ameid to determine the effect of Transactional Analysis (TA) training to increase interpersonal communication skills in nurses in executif Hospital Nusa Indah Dr Adhyatma, Central of Java. The proposed hypothesis of this study is that there is an interpersonal communication skills between subjectcts who received TA training with subjects who did not receive TA training, there are differences in interpersonal communication skills scores in the experimental group before and after TA training. The study subjects were 10 nurses in executif Hospital Nusa Indah Dr. Adhyatma, Central of Java. Subjects were divided into 2 groups: 5 subjects as the experimental group, and 5 subjects as a control group. The placement of the subjects in a randomized group. The design used in this study is a randomized pretest-posttest control group. Measurements were performed by measuring the pre-test, post test and follow-up using interpersonal communication skills scale. The analytical method used is a non-parametric
\end{abstract}


analysis (Mann-Whitney test and the Wilcoxon test). Hypothesis test results produce value $Z=$ $2,032(p<0,01)$, meaning that there is a difference between interpersonal communication skills experimental group and control group. Difference in mean score of interpersonal communication skills experimental group $(69,4)$ is greater than the control group $(-5,8)$, so that the research hypothesis is accepted. In the experimental group $(Z=-2,023 ; p<0,01)$ which showed no significant difference between before and after training, with an increase in the mean score of 71,6 so the hypothesis is also accepted.

Keywords : transactional analysis, interpersonal communication skills

\section{PENDAHULUAN}

Kesehatan merupakan suatu hal penting dalam kehidupan manusia, banyak rumah sakit dapat dijadikan tempat untuk berobat, tetapi tidak semua rumah sakit memperhatikan pelayanan dan kesejahteraan psikologis pasien-pasiennya, padahal menurut hasil-hasil penelitian tentang kesehatan seseorang, selain dipengaruhi oleh keadaan biologis dan sosial juga dipengaruhi keadaan psikologis (Durand \& Barlow, 2006). Sejalan dengan hal itu Spacapan \& Oskamp (1994) mengatakan, bahwa keadaan psikologis yang baik memiliki efek positif pada kesehatan. Efek positif dalam hubungan tenaga medis dapat berupa dukungan sosial yang dapat diperoleh dari berbagai pihak, antara lain keluarga, kerabat, teman-teman, perawat, dan dokter. Dalam hubungan tenaga medis bentuk dukungan sosial yang mungkin dapat diberikan selain tindakan-tindakan medis melalui obat-obatan dan tindakan farmaka lainnya adalah komunikasi (Symister \& Friend, 2003). Menurut Wasisto dkk (2006), komunikasi yang efektif dapat membuat orang lain merasa nyaman dan aman berada dalam penanganan tenaga medis.

Komunikasi adalah sebuah proses penyampaian pikiran-pikiran atau informasi dari seseorang kepada orang lain melalui suatu cara tertentu sehingga orang lain tersebut mengerti betul informasi atau pikiran-pikiran yang disampaikan (Walgito, 2003). Menurut Schramm (Suprapto, 2008) komunikasi dapat berlangsung dengan melibatkan paling sedikit tiga unsur komunikasi yaitu; sumber (komunikator), pesan dan sasaran (komunikan). Komunikasi sebagai salah satu kompetensi yang menentukan keberhasilan pelayanan kesehatan. Menurut Wasisto dkk (2006), pada umumnya tindakan berobat kepada tenaga medis dilakukan seseorang sebagai usaha mencari bantuan atau pertolongan atas ketidakmampuannya untuk menangani masalah kesehatan yang sedang dialaminya. Tenaga medis dalam penelitian ini adalah perawat. Perawat sebagai profesi merupakan salah satu pekerjaan yang menyaratkan tindakannya didasari pada ilmu pengetahuan serta memiliki keterampilan yang jelas dalam keahliannya. Salah satunya adalah memberikan layanan keperawatan disesuaikan dengan keunikan klien dan tidak terpengaruh oleh faktor-faktor agama, budaya, umur dan jenis kelamin (Muwarni, 2009). Dalam pengabdiannya, seorang perawat ditempatkan di suatu ruangan tertentu dan seringpula harus bertugas giliran di ruangan lain, atau berasal dari latar belakang usia berbeda (Gunarsa \& Gunarsa, 2008). 
Selain hal-hal tersebut di atas, kesadaran diri, kemampuan menjadi model peran dan rasa tanggung jawab merupakan bagian dari kualitas personal yang butuh dikembangkan oleh seorang perawat (Stuart, 2006). Hal penting lainnya yang harus dikembangkan dalam diri perawat adalah kemampuan diri dalam setiap peristiwa atau keadaan yang menuntut seseorang untuk dapat mengaktualisasikan potensi dirinya. Salah satu kemampuan penting dalam proses layanan keperawatan adalah kemampuan komunikasi yang digunakan sebagai jembatan untuk menghubungkan manusia satu dengan yang lainnya. Pasien yang berobat ke rumah sakit banyak melakukan komunikasi dengan tenaga medis selama melakukan pengobatan terhadap penyakit yang diidapnya.

Melihat peran sentral tenaga medis tersebut maka kemampuan dengan interaksi kemampuan komunikasi diharapkan mampu menambah kemampuan para perawat sebagai tenaga medis. Komunikasi menjadi sarana terciptanya ide bersama, perasaan kebersamaan melalui tukar menukar pesan (informasi), menggambarkan emosi dan kebutuhan mulai dari yang paling sederhana sampai yang kompleks. Hakikat penting dalam komunikasi dalam layanan keperawatan adalah proses pernyataan antar manusia, yaitu melalui pikiran atau perasaan seseorang kepada orang lain dengan menggunakan bahasa sebagai alat penyalurnya (Effendy, 2004). Kemampuan komunikasi sesungguhnya merupakan salah satu fenomena dalam kehidupan sosial. Artinya setiap individu pasti akan melakukan komunikasi dalam kehidupannya, akan tetapi kemampuannya untuk melakukan komunikasi secara efektif pada setiap individu pastilah berbeda-beda karena adanya perbedaan individual, bahkan sering sekali terjadinya miskomunikasi dan kesalahpahaman dalam komunikasi.

Walgito (2003) mengatakan, bahwa manusia pada dasarnya adalah makhluk sosial, manusia secara alami selalu membutuhkan hubungan atau komunikasi dengan manusia lain. Menurut hasil penelitian tentang kesehatan seseorang, selain dipengaruhi oleh keadaan biologis dan sosial juga dipengaruhi oleh keadaan psikologis (Durand \& Barlow, 2006). Keadaan psikologis ini salah satunya berkaitan erat dengan komunikasi. Katz (Walgito, 2003) mengatakan, bahwa komunikasi merupakan salah satu proses sosial. Oleh karena itu, jika berada dalam situasi berkomunikasi, maka seseorang perlu memiliki beberapa kesamaan dengan orang lain, seperti kesamaan bahasa atau kesamaan arti dari simbol-simbol yang digunakan dalam berkomunikasi (Cangara,2006). Katz (Walgito, 2003) mengatakan, bahwa komunikasi merupakan salah satu proses sosial. Berdasarkan hasil wawancara awal yang dilakukan peneliti di poli eksekutif Paviliun Nusa Indah RSUD dr. Adhyatma MPH Provinsi Jawa Tengah kepada pimpinan, kepala perawat poli eksekutif Nusa Indah dan salah satu perawat pada bulan Januari 2015, didapat informasi adanya kecenderungan perawat yang kurang mampu memberikan layanan memuaskan dan kebiasan perawat ketika di bangsal terbawa pada saat memberikan pelayanan di Poli Eksekutif Nusa 
Indah, karena terbatasnya kemampuan komunikasi dan interaksi antara perawat dengan dokter, perawat dengan sesama perawat dan perawat dengan pasien terkadang membuat perawat saling menyalahkan satu sama lain serta jarang berinteraksi dalam bekerja cenderung membuat mereka bekerja sendiri-sendiri. Padahal interaksi berupa keterbukaan, empati, dukungan, kepositifan, serta kesetaraan dan komunikasi dalam proses layanan medis itu seharusnya berlangsung secara efektif, karena satu sama lain akan saling mempengaruhi. Hasil penggalian informasi lebih lanjut melalui observasi di poli eksekutif Nusa Indah kualitas layanan memperlihatkan bahwa dari segi penampilan fisik para perawat tersebut sudah nampak menarik sehingga semestinya menjadi representasi layanan yang menyenangkan pula, tetapi kenyataannya tingkat kemampuan berkomunikasi para perawat yang bertugas di poli eksekutif Nusa Indah relatif rendah baik dengan sesama perawat, dokter maupun pasien. Hal ini nampak dari cara perawat ketika menemui masalah cenderung menyelesaikannya sendiri-sendiri, tidak peduli dengan kesulitan orang-orang disekitarnya, lepas tanggung jawab apabila orang disekitarnya terkena masalah, seringkali tidak menghargai orang lain, serta merasa posisinya tidak selevel dengan lingkungan disekitarnya. Oleh karena itu diperlukan kemampuan komunikasi di bidang layanan kesehatan.

Menurut Wawuru (2011) tenaga medis yang mampu berkomunikasi secara efektif akan bermanfaat bagi rekan sesama perawat, dokter dan pasien guna mengetahui informasi, tentang penyakitnya, peluang dan harapan akan kepulihannya. Kepedulian, dukungan dan profesionalisme dari tenaga medis yakni perawat membuat rekan sesama perawat, dokter dan pasien optimis dalam menghadapi dan menemui suatu penyakit. Pentingnya komunikasi sebagai salah satu skill helper sejalan dengan pendapat Egan (2010), yakni untuk mencapai tujuan dan harapan yang ingin dicapai dalam kehidupan maka seseorang harus memiliki komitmen dalam dirinya sendiri . Oleh karena itulah kemampuan komunikasi dijadikan sebagai fokus utama dalam penelitian ini, karena kemampuan komunikasi penting artinya sebagai bekal individu untuk memberikan layanan medis yang memuaskan.

Ada beberapa teknik untuk meningkatkan kemampuan komunikasi, antara lain model diskusi, pembelajaran andragogi, visualisasi dan pelatihan Analysis Transactional (AT). Munculnya indikasi masalah kemampuan komunikasi perawat dalam membangun hubungan interaksi baik dengan sesama perawat, dokter, dan pasien maupun orang-orang dalam lingkup keperawatan serta keunikan metode analisis transaksional, menjadi dasar peneliti untuk melihat seberapa jauh efektifitas pelatihan analisis transaksional terhadap peningkatan kemampuan komunikasi perawat. AT merupakan karya besar Eric Berne (dalam Mawikere, 2012), yang ditulisnya dalam buku Games People Play. Berne adalah seorang ahli ilmu jiwa terkenal dari kelompok Humanisme. Teori analisis transaksional merupakan teori tentang terapi yang sangat populer dan 
digunakan dalam konsultasi pada hampir semua bidang ilmu-ilmu perilaku. Teori analisis transaksional telah menjadi salah satu teori komunikasi antarpribadi yang mendasar. AT berasumsi bahwa orang-orang bisa belajar memercayai dirinya sendiri, berpikir dan memutuskan untuk dirinya sendiri dan mengungkapkan perasaan-perasaannya (Nabrady, 2005; de Blot, 1992), menelusuri pengalaman-pengalaman menyedihkan sebagai manifestasi dari suatu kebuntuan, konflik intra psikis, dan atau hambatan interpersonal terutama menyangkut pola komunikasi dari masing-masing pihak ketika berinteraksi (Spanceley, 2009). AT menyediakan petunjuk dan arahan mengenai bagaimana cara berespon saat berada dalam situasi yang menekan atau mengancam diri (Chakraborty dalam Mawikere, 2012). Bahkan dalam teori Orem (Agthoven \& Plomp dalam Mawikere, 2012) disebutkan bahwa pelayanan perawatan dan model AT mendukung pemenuhan hubungan kontraktual dengan sesama perawat, dokter, dan pasien dengan menitikberatkan pada kerjasama serta keputusan bersama untuk suatu proses pelayanan medis. Sebaliknya jika yang terjadi adalah ketidaksepahaman maka perawat dengan sesama perawat, dokter, dan pasien akan lebih sering terlibat dalam pola transaksi silang (crossed transactional) atau perbedaan transaksi status ego yang merupakan pola interaksi diluar ciri terapeutik (Parissopoulos \& Kotzabassaki, 2004). Ketepatan penerapan anlisis transaksional dalam kelompok menjadi pertimbangan, oleh karena para peserta dalam suatu kelompok akan secara langsung menerapkan ciri transaksi status ego serta situasi kelompok memungkinkan dinamika perilaku yang berlangsung secara spontan ( Spanceley, 2009; Schmid, 2008). Terkait penerapan dalam lingkungan keperawatan, maka pendekatan analisis transaksional dapat membantu upaya perawat mengantisipasi setiap tekanan yang dirasakan dengan terlebih dahulu menganalisis situasi sebelum bertransaksi dan berinteraksi dengan cara mengaktifkan status ego yang tepat pada situasi transaksi yang sesuai. Pengaktifan status ego yang tepat dalam berinteraksi akan memicu antisipasi perawat dalam menghadapi setiap kemungkinan yang akan terjadi ketika berinteraksi dengan orang lain (Florio dkk, 1988; Greenberg, 2002).

\section{METODE}

\section{Subjek Penelitian}

Subjek penelitian adalah perawat poli eksekutif di Paviliun Nusa Indah RSUD Adhyatma MPH Provinsi Jawa Tengah yang memiliki karakteristik subjek penelitian sebagai berikut:

1. Berusia $21-45$ tahun. Menurut Santrock (2012), pada usia 21 tahun yang berakhir pada usia 30-an tahun disebut dengan masa dewasa awal. Periode perkembangan yang diawali pada kira-kira usia 35 hingga 45 tahun disebut dengan masa pertengahan dewasa. Schaie \& Willis (Santrock, 2012) menyatakan pada usia tersebut individu sudah memiliki kemampuan berpikir seflektif sehingga diharapkan dapat memahami proses latihan AT. 
2. Tidak sedang mengikuti konseling dan psikoterapi lebih dari satu kali dalam setiap bulannya. Hal ini diperkirakan akan memengaruhi intervensi yang akan diberikan.

3. Subjek yang digunakan dalam penelitian ini adalah subjek yang memiliki skor kemampuan komunikasi interpersonal 4560 dengan kategori rendah dan 61-120 dengan kategori sedang.

\section{Desain Penelitian}

Penelitian ini menggunakan desain eksperimen randomized pretest-posttest kontrol group design yang terdiri dari 2 kelompok yaitu kelompok eksperimen dan kelompok kontrol sebagai pembanding (Latipun, 2006). Kelompok eksperimen adalah kelompok partisipan yang mendapatkan pelatihan AT yang terbagi dalam beberapa materi dan 9 sesi selama tiga hari. Pelatihan AT dilakukan dengan menggunakan metode roleplay, diskusi, dan ceramah sesuai dengan modul Pelatihan AT. Kelompok kontrol adalah kelompok partisipan yang diberikan perlakuan berupa pelatihan yang sama namun dengan menggunakan metode waiting list. Hal ini dilakukan dengan tujuan untuk mengetahui perbedaan kemampuan komunikasi diantara subjek yang diberikan Pelatihan AT dengan subjek yang tidak diberikan Pelatihan AT.

\section{Metode Pengumpulan Data}

Alat pengumpulan data yang digunakan untuk mengukur variabel kemampuan komunikasi adalah Skala Kemampuan Komunikasi Interpersonal berpedoman pada indikator kemampuan komunikasi menurut De
Vito (Suprapto, 2008). Skala Kemampuan Komunikasi Interpersonal disusun oleh peneliti berdasarkan indikator yang sudah ada. Subjek diminta untuk menjawab pertanyaan dengan cara memilih salah satu dari alternatif jawaban yang tersedia antara lain ialah Sangat Sesuai, Sesuai, Tidak Sesuai, dan Sangat Tidak Sesuai. Skor pada pertanyaan favorable bergerak dari 4 sampai 1, nilai 4 tertinggi diberikan pada jawaban Sangat Sesuai, 3 untuk jawaban Sesuai, 2 untuk jawaban Tidak Sesuai, 1 untuk jawaban Sangat Tidak Sesuai. Sebaliknya skor untuk pertanyaan unfavorable bergerak dari 1 sampai 4. Nilai 4 untuk jawaban Sangat Tidak Sesuai, 3 untuk jawaban Tidak Sesuai, 2 untuk jawaban Sesuai, dan 1 untuk jawaban Sangat Sesuai. Semakin tinggi skor berarti subjek memiliki tingkat kemampuan komunikasi yang tinggi. Aitem skala Kemampuan Komunikasi Interpersonal setelah dilakukan uji cob memiliKI indeks daya beda berkisar antara 0,312-0,716. Nilai alpha cronbach memperlihatkan koefiseien sebesar 0,933 sehingga dapat disimpulkan bahwa Skala Kemampuan Komunikasi Interpersonal memiliki reliabilitas yang baik (Azwar, 2011).

\section{Intervensi Pelatihan}

Modul AT yang digunakan oleh peneliti merupakan modul milik Mawikere (2012) yang meneliti pengaruh pelatihan AT terhadap peningkatan kemampuan komunikasi interpersonal perawat di Rumah Sakit X. modul yang dibuat oleh Mawikere (2012) ini mengacu pada metode pelatihan AT menurut Berne dalam Mawikere, 2012. Modul 
pelatihan ini terdiri dari 3 tehnik yang terdiri dari: (a) Transaksi sejajar (complimenter transaction). Transaksi ini dapat terjadi jika diantara stimulus dan respon mengalami kesesuaian atau kecocokkan, tepat dan memang diharapkan, sehingga transaksi ini akan berjalan lancar; (b) Transaksi silang (crossed transaction). Transaksi ini terjadi jika antara stimulus dan respon tidak cocok atau berlangsung tidak sebagaimana yang diharapkan oleh salah satu pihak bahkan keduanya; (c) Transaksi tersembunyi (uleration transaction). Transaksi ini terjadi jika antara dua status ego beroperasi bersamasama.

\section{Metode Analisis Data}

Analisis yang digunakan adalah metode statistik untuk menguji perbedaan kemampuan komunikasi antara kelompok eksperimen yang diberikan perlakuan dengan kelompok kontrol yang diberikan perlakuan dengan teknik analisis Mann Whitney Test. Teknik Mann Whitney Test digunakan untuk menguji perbedaan tingkat kemampuan komunikasi interpersonal antara kelompok eksperimen dengan kelompok kontrol. Data yang akan dianalasis adalah "gain score" yaitu selisih nilai skor pretest dan skor posttest dan followup. Untuk mengetahui kelompok mana yang memiliki kemampuan komunikasi lebih tinggi dilihat melalui rata-ratanya. Analisis statistik selanjutnya adalah dengan menggunakan teknik analisis Wilcoxon Test untuk menguji perbedaan kemampuan komunikasi interpersonal pada subjek sebelum diberikan pelatihan, sesudah diberikan pelatihan dan tindak lanjut sesudah diberikan pelatihan pada kelompok eksperimen. Data yang akan dianalisis adalah "skor pretest, posttest dan follow-up pada subjek dalam kelompok eksperimen.

\section{HASIL DAN PEMBAHASAN}

Data yang diperoleh dari pretest dan posttest serta follow-up skala kemampuan komunikasi interpersonal digunakan sebagai dasar pengujian hipotesis. Data penelitian yang diperoleh dianalisis menggunakan tiga cara, analisis deskriptif untuk menggambarkan dinamika perubahan psikologis yang dialami masing-masing subjek pada kelompok eksperimen, analisis statistikan Non Parametrik (Mann-Whitney Test) yang digunakan untuk melihat perbedaan kemampuan komunikasi interpersonal antara kelompok eksperimen dan kelompok kontrol berdasarkan perbedaans selisih antara posttest dan pretest serta follow-up (gain score) sesudah pelatihan AT, dan analisis kualitatif (untuk melihat perubahan dan perkembangan setiap subjek dari awal sampai akhir proses penelitian).

\section{Data deskriptif}

Skala kemampuan komunikasi interpersonal memiliki skor minimal hipotetik sebesar 45, skor maksimal hipotetik 180 , standar deviasi hipotetik sebesar 22,5 dan ratarata hipotetiknya adalah 112,5. Hasil data empirik pada pengumpulan data skor pretest menunjukkan skor kemampuan komunikasi interpersonal pada kelompok ekseperimen minimal 56 dan skor maksimal 80 dengan ratarata 67. Pada kelompok kontrol skor 
kemampuan komunikasi interpersonal minimal 57 dan skor maksimal 85 dengan rata-rata 69,6. Skor posttest menunjukkan skor kemampuan komunikasi interpersonal pada kelompok ekseperimen skor minimal 127 dan skor maksimal 157 dengan rata-rata 136,4. Pada kelompok kontrol skor kemampuan komunikasi interpersonal skor minimal 54 dan skor maksimal 74 dengan rata-rata 63,8 . Skor follow-up menunjukkan skor kemampuan komunikasi interpersonal pada kelompok ekseperimen minimal 127 dan skor maksimal 154 dengan rata-rata 138,6. Pada kelompok kontrol skor kemampuan komunikasi interpersonal minimal 56 dan skor maksimal 78 dengan rata-rata 65,8. Deskripsi data deskriptif penelitian dapat dilihat pada Tabel 1 berikut ini.

Tabel 1. Data Deskriptif

\begin{tabular}{|c|c|c|c|c|c|}
\hline \multirow{2}{*}{\multicolumn{2}{|c|}{$\begin{array}{c}\text { Kemampuan } \\
\text { komunikasi efektif }\end{array}$}} & \multicolumn{4}{|c|}{ Skor } \\
\hline & & $\mathrm{Mi}$ & $\mathrm{Ma}$ & Mea & SD \\
\hline \multirow[t]{3}{*}{$\begin{array}{l}\text { Hipotet } \\
\text { ik }\end{array}$} & & 45 & 180 & $\begin{array}{c}112, \\
5\end{array}$ & 22,5 \\
\hline & $\begin{array}{l}\text { Eksperi } \\
\text { men }\end{array}$ & 56 & 80 & 67 & 10,4 \\
\hline & Pretest & 12 & 153 & 136, & 88 \\
\hline \multirow{11}{*}{$\begin{array}{l}\text { Empiri } \\
\mathrm{k}\end{array}$} & Posttest & 7 & 154 & 4 & 10,2 \\
\hline & Follow- & 12 & & 138, & 86 \\
\hline & $U p$ & 7 & 85 & 6 & 10,2 \\
\hline & Kontrol & & 74 & & 62 \\
\hline & Pretest & 57 & 78 & 69,6 & \\
\hline & Posttest & 54 & & 63,8 & 13,0 \\
\hline & Follow- & 56 & & 65,8 & 69 \\
\hline & $U p$ & & & & 8,19 \\
\hline & & & & & 8 \\
\hline & & & & & 10,1 \\
\hline & & & & & 83 \\
\hline
\end{tabular}

\section{Hasil Analisis Hipotesis}

Pengujian hipotesis dilakukan dengan uji statistik dengan menggunakan mannwhitney $U$ (U-test), untuk melihat pengaruh

pelatihan AT terhadap kemampuan komunikasi interpersonal. Hasil analisis data dengan U-test dapat dilihat pada Tabel 2.

Tabel 2 di bawah menunjukkan bahwa ada perbedaan skor antara kemampuan komunikasi interpersonal yang signifikan antara kelompok eksperimen dengan kelompok kontrol pada pengukuran selisih pretest-posttest (gain score 1) dengan $\mathrm{Z}=$ $2,611 \quad(\mathrm{p}<0,001)$. Ada perbedaan skor kemampuan komunikasi interpersonal yang signifikan antara kelompok eksperimen dengan kelompok kontrol pada pengukuran selisih pretest dan follow-up (gain score 2) dengan $Z=-2,193(p<0,05)$. Dengan demikian hipotesis penelitian ini diterima yaitu ada perbedaan kemampuan komunikasi interpersonal perawat yang diberikan pelatihan AT dengan perawat yang tidak diberikan pelatihan AT.

Tabel 2. Rangkuman Test U-Mann-Whitney

\begin{tabular}{|c|c|c|}
\hline Sumber & Z & $\begin{array}{c}p \\
\text { (signifikan) }\end{array}$ \\
\hline Gain Score 1 & 2,611 & $\mathrm{p}<0,001$ \\
\hline Gain Score 2 & 2,193 & $\mathrm{P}<0,005$ \\
\hline
\end{tabular}

Selanjutnya untuk melihat perbedaan skor kemampuan komunikasi interpersonal tersebut, maka rata-rata skor pada setiap pengukuran dapat dilihat pada Tabel 3 di bawah ini.

Tabel 3. Perbedaan Rata-rata Skor Kemampuan Komunikasi Interpersonal

\begin{tabular}{ccccc} 
Kelompok & \multicolumn{2}{c}{ Kelompok } & \multicolumn{2}{c}{ Kelompok } \\
& \multicolumn{2}{c}{ Eksperimen } \\
Mean & $\begin{array}{c}\text { Selisi } \\
\text { Kontrol }\end{array}$ & $\begin{array}{c}\text { Mea } \\
\text { n }\end{array}$ & $\begin{array}{c}\text { Selisi } \\
\text { h }\end{array}$ \\
\hline Pre-test & 67,0 & & 69,6 & \\
Post-test & 136,4 & & 69,4 & \\
& & 2,2 & & 2 \\
\hline
\end{tabular}




Follow-up 138,6 65,8
Rata-rata skor kemampuan komunikasi
interpersonal pada kelompok eksperimen lebih
tinggi daripada rata-rata skor kemampuan
komunikasi interpersonal, baik pada
pengukuran sesudah perlakuan maupun
pengukuran tindak lanjut. Perbedaan rata-rata
skor kemampuan komunikasi interpersonal
antara kelompok eksperimen dan kelompok
kontrol juga dapat dilihat pada Gambar 2
histogram di bawah ini.

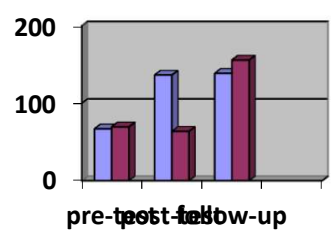

口Eksperimen

口Kontrol

Gambar 1. Histogram Rata-Rata Skor

Kemampuan Komunikasi Interpersonal pada Masing-Masing Pengukuran

Gambar 1 di atas menunjukkan bahwa pada kelompok eksperimen terjadi peningkatan tingkat kemampuan komunikasi interpersonal dibandingkan kelompok kontrol pada pengukuran segera sesudah pelatihan (posttest) dan pengukuran tindak lanjut (follow-up). Selanjutnya untuk melihat apakah ada peningkatan kemampuan komunikasi interpersonal pada kelompok eksperimen signifikan, dilakukan dengan analisis tambahan dengan Uji Wilcoxon. Hasil analisis tersebut dapat dilihat pada Tabel 4 berikut ini:

Tabel 4. Ringkasan Hasil Peningkatan Skor Kemampuan Komunikasi Interpersonal pada Kelompok Eksperimen

\begin{tabular}{cccc}
\hline Sumber & $\begin{array}{c}\text { Rata-rata } \\
\text { Peningkatan }\end{array}$ & $\mathrm{Z}$ & $\mathrm{P}$ \\
\hline Pretest & 69,4 & - & 0,042 \\
\hline
\end{tabular}

\begin{tabular}{lccc}
\hline dengan & & 2,032 & $(<$ \\
posttest & & & $0,05)$ \\
Pretest & 71,6 & - & 0,043 \\
dengan & & 2,023 & $(<$ \\
follow-up & & & $0,05)$ \\
Posttest & 2,2 & - & 0,033 \\
dengan & & 1,841 & $(<$ \\
follow-up & & & $0,05)$ \\
\hline
\end{tabular}

Dari tabel 4 di atas diketahui bahwa terdapat perbedaan yang signifikan antara skor kemampuan komunikasi interpersonal sebelum (pretest) dan sesudah pelatihan (posttest) dengan $Z=-2,032(p<0,05)$ dengan rata-rata peningkatan kemampuan komunikasi interpersonal sebesar 69,4. Hasil analisis skor kemampuan komunikasi interpersonal sebelum dan saat tindak lanjut dengan $Z=-2,023$ $(\mathrm{p}<0,05), \quad$ serta rata-rata peningkatan kemampuan komunikasi interpersonal sebesar 71,6. Dari hasil analisis juga diketahui bahwa terdapat perbedaan yang signifikan antara skor kemampuan komunikasi interpersonal pada saat sesudah pelatihan dan tindak lanjut dengan $Z=-1,841(p<0,05)$, serta rata-rata peningkatan kemampuan komunikasi interpersonal sebesar 2,2. Hal ini berarti pelatihan AT masih memberikan efek samping pada saat pengukuran tindak lanjut. Dengan demikian hipotesis penelitian ini diterima, yaitu ada perbedaan kemampuan komunikasi interpersonal pada perawat sebelum dan sesudah diberikan pelatihan AT. Gambar 1 pretest - posttest - follow-up menunjukkan pada kelompok kontrol terjadi penurunan tingkat kemampuan komunikasi interpersonal pada pengukuran sesudah pelatihan (posttest) dan terjadi peningkatan setelah pengukuran tindak lanjut (follow-up). Selanjutnya untuk melihat apakah penurunan kemampuan 
komunikasi interpersonal pada kelompok kontrol signifikan, juga dilakukan analisis tambahan dengan test Wilcoxon. Hasil analisa tersebut dapat dilihat pada Tabel 5 berikut ini.

Tabel 5. Ringkasan Hasil Rata-Rata Peningkatan Skor Kemampuan Komunikasi Interpersonal pada Kelompok Kontrol

\begin{tabular}{cccc}
\hline Sumber & $\begin{array}{c}\text { Rata-rata } \\
\text { Peningkatan }\end{array}$ & $\mathrm{Z}$ & $\mathrm{P}$ \\
\hline $\begin{array}{c}\text { Pretest } \\
\text { dengan }\end{array}$ & $-5,8$ & - & 0,144 \\
posttest & & 1,461 & $(>0,05)$ \\
$\begin{array}{c}\text { Pretest } \\
\text { dengan }\end{array}$ & $-3,8$ & 1,826 & 0,034 \\
follow-up & & & $(<0,05)$ \\
$\begin{array}{c}\text { Posttest } \\
\text { dengan }\end{array}$ & 2 & 0,730 & 0,465 \\
follow-up & & & $(>0,05)$ \\
\hline
\end{tabular}

Hasil Tabel 5 di atas diketahui tidak terdapat perbedaan yang signifikan antara skor kemampuan komunikasi interpersonal sebelum (pretest) dan sesudah pelatihan (posttest) dengan $Z=-1,461$ dan $p=0,144(p>0,05)$, dengan rata-rata penurunan tingkat kemampuan komunikasi interpersonal sebesar $-5,8$. Hasil analisis tersebut juga menunjukkan terdapat perbedaan signifikan antara skor kemampuan komunikasi interpersonal sebelum (pretest) dan saat tindak lanjut (follow-up) dengan $Z=1,826$ dan $\mathrm{p}=0,034(\mathrm{p}<0,05)$, pada pengukuran ini terjadi penurunan skor kemampuan komunikasi interpersonal sebesar $-3,8$. Dari hasil analisis juga diketahui bahwa terdapat perbedaan nilai yang signifikan antara skor kemampuan komunikasi interpersonal pada saat sesudah pelatihan (postest) dan tindak lanjut (follow-up) dengan $\mathrm{Z}=0,730$ dan $\mathrm{p}=0,465(\mathrm{p}>0,05)$, juga pada saat pengukuran ini terjadi kenaikan skor kemampuan komunikasi interpersonal sebesar 2.

Secara keseluruhan, hal ini menunjukkan bahwa partisipan yang tidak mendapatkan pelatihan AT tidak mengalami peningkatan kemampuan komunikasi interpersonal yang signifikan atau dengan kata lain, partisipan yang tidak mendapatkan pelatihan mengalami penurunan skor kemampuan komunikasi interpersonal. Antara kemampuan komunikasi interpersonal sebelum (pretest) dan saat tindak lanjut (follow-up) menunjukkan peningkatan skor kemampuan komunikasi interpersonal yang signifikan, dari hasil analisis juga diketahui sesudah (pottest) dan saat tindak lanjut (follow-up) menunjukkan peningkatan skor kemampuan komunikasi interpersonal yang signifikan.

\section{Hasil analisis individual}

Secara keseluruhan, seperti ini terlihat pada histogram terjadi peningkatan skor kemampuan komunikasi interpersonal sebelum diberikan pelatihan AT, dan sesudah diberikan pelatihan AT. Hal ini menunjukkan bahwa pelatihan AT efektif meningkatkan kemampuan komunikasi interpersonal pada perawat. Selain histogram, analisis kualitatif dilakukan pada kelompok eksperimen. Tujuan analisis kualitatif adalah untuk mengetahui pengalaman peserta dalam mengikuti masingmasing sesi pelatihan dan pengalaman emosional yang dirasakan setelah melakukan pelatihan.

\section{Peserta Nomor $1(C)$}

Secara umum, C tampak aktif dan antusias mengikuti pelatihan. $\mathrm{C}$ aktif 
mengemukakan pendapatnya. Selain itu $\mathrm{C}$ juga selalu melakukan kemampuan komunikasi interpersonal di kantor, di rumah dan dalam kehidupan sehari-hari. C bekerja selama kurang lebih 3 bulan di poli eksekutif Nusa Indah. Selama menjadi perawat di poli eksekutif Nusa Indah, C merasa cukup menyukai pekerjaannya. Skor skala kemampuan komunikasi interpersonal $\mathrm{C}$ sebelum pelatihan adalah 56 dan setelah pelatihan 138, artinya C mengalami peningkatan skor kemampuan komunikasi interpersonal sebesar 82 poin. Pada follow-up yang dilakukan satu minggu setelah pelatihan, skor kemampuan komunikasi interpersonal meningkat menjadi 141 artinya ada peningkatan skor kemampuan komunikasi interpersonal satu minggu setelah pelatihan berakhir dari kategori rendah menjadi kategori tinggi. Hal ini dikarenakan, $\mathrm{C}$ tetap melakukan berbagai tekhnik AT untuk menghadapi berbagai situasi dan kondisi dalam kehidupan sehari-harinya walaupun pelatihan telah berakhir. Selama menjalani pelatihan, C menunjukkan motivasi dan rasa ingin tahu yang besar dalam mengikuti masing-masing sesi. Selain itu, $\mathrm{C}$ juga menunjukkan keinginan yang besar untuk mencoba hal-hal baru yang dipelajari selama proses pelatihan. $\mathrm{C}$ cukup kooperatif dan terbuka terhadap pengalamannya hal ini terlihat dari keinginan C untuk selalu berusaha melaksanakan setiap instruksi yang diberikan pada saat pelatihan di masing-masing sesi pelatihan. Secara keseluruhan $\mathrm{C}$ melaksanakan pelatihan dengan antusias dan serius. Setelah melaksanakan pelatihan $\mathrm{C}$ mulai menyadari bahwa selama ini dirinya sangat tidak memahami dirinya, sehingga secara tidak sadar hal ini mengganggu kehidupannya sehari-hari.

Pada proses follow-up (setelah satu minggu setelah pelatihan), $\mathrm{C}$ menceritakan pengalamannya yang tetap rutin dalam melakukan kemampuan komunikasi interpersonal dalam kehidupan sehari-hari. C melakukan kemampuan AT ketika mengalami kondisi yang mengharuskan dirinya mengubah status ego baik di rumah maupun di tempat kerja. C paling sering menggunakan tekhnik mengenal diri karena paling banyak manfaat yang dirasakan $\mathrm{C}$ setelah menggunakannya yaitu merasa lebih dapat mengendalikan ego dan lebih dapat berpikir positif ketika menghadapi berbagai situasi dan kondisi. Serta lebih dapat memahami dan menghargai keadaan yang dirasakan.

\section{Peserta Nomor 2 (A)}

Secara umum, A tampak aktif dan antusias mengikuti pelatihan. A aktif mengemukakan pendapatnya. Selain itu A juga selalu melakukan pelatihan kemampuan komunikasi interpersonal pada masing-masing tekhnik di rumah dan dalam kehidupan seharihari. Selama menjadi perawat di poli eksekutif Nusa Indah A banyak mendapatkan banyak pengalaman baru. A sudah bekerja kurang lebih 3 bulan dan 2 tahun di bangsal. Hal ini terungkap pada saat sharing di awal bahwa A merasa selama bekerja, A merasa senang bekerja walaupun ketika banyak masalah dirinya sulit untuk mengungkapkan perasaannya kepada orang tedekat sekalipun. Skor skala kemampuan komunikasi interpersonal sebelum pelatihan adalah 68 dan 
setelah pelatihan 129 , artinya A mengalami peningkatan skor kemampuan komunikasi interpersonal dari kategori rendah menjadi katyegori tinggi.

Pada follow-up yang dilakukan satu minggu setelah pelatihan, skor kemampuan komunikasi interpersonal meningkat menjadi 132 artinya ada peningkatan skor kemampuan komunikasi interpersonal satu minggu setelah pelatihan berakhir sebesar 3 poin daripada skor sebelumnya. Hal ini dikarenakan, A tetap melakukan berbagai teknik AT untuk mengatasi setiap situasi dan kondisi dalam kehidupan sehari-harinya walaupun pelatihan telah berakhir. Selama menjalani pelatihan, A menunjukkan motivasi dan rasa ingin tahu yang besar dalam mengikuti masing-masing sesi. Selain itu, A juga menujukkan keinginan yang besar untuk mencoba hal-hal baru yang dipelajari selama proses pelatihan. A cukup kooperatif dan terbuka terhadap pengalamannya, hal ini terlihat dari keinginan A untuk selalu berusaha melaksanakan setiap instruksi yang diberikan pada saat pelatihan di masing-masing sesi pelatihan. Secara keseluruhan A melaksanakan pelatihan dengan antusias dan serius. Setelah melaksanakan pelatihan A mulai menyadari bahwa selama ini dirinya sangat tidak memahami dirinya, sehingga A tidak mampu menceritakan masalahnya kepada orang lain. Pada proses follow-up (setelah satu minggu setelah pelatihan), A menceritakan pengalamannya yang tetap rutin dalam melakukan kemampuan komunikasi interpersonal dalam kehidupan sehari-hari. A melakukan kemampuan AT ketika mengalami kondisi yang mengharuskan dirinya mengubah status ego baik di rumah maupun di tempat kerja. A paling sering menggunakan tekhnik posisi hidup karena paling banyak manfaat yang dirasakan C setelah menggunakannya yaitu merasa lebih dapat mengetahui posisi diri dan lebih dapat berpikir positif ketika menghadapi berbagai situasi dan kondisi. Serta lebih dapat memahami dan menghargai keadaan yang dirasakan.

\section{Peserta Nomor 3 (L)}

L sudah bekerja selama kurang lebih 6 tahun di bangsal dan 1 tahun di poli eksekutif Nusa Indah . Selama menjadi perawat L kurang menyukai pekerjaannya. Hal ini terungkap pada saat sharing di awal pelatihan bahwa L merasa selama bekerja, L merasa terbebani ketika menghadapi pasien yang terlampau susah untuk diurus, sehingga terkadang membuat $\mathrm{L}$ merasa tertekan dan menghindari banyak orang ketikan sedang ada masalah. Secara umum, L tampak aktif dan antusias mengikuti pelatihan. L aktif mengemukakan pendapatnya. Selain itu L juga selalu melakukan pelatihan AT pada masingmasing teknik dirumah dan dalam kehidupan sehari-hari setiap sesinya. Skor kemampuan komunikasi interpersonal sebelum pelatihan adalah 74 dan setelah pelatihan 135, artinya L mengalami peningkatan skor kemampuan komunikasi interpersonal sebesar 61 poin.

Pada follow-up yang dilakukan satu minggu setelah pelatihan, skor kemampuan komunikasi interpersonal meningkat menjadi 139 artinya ada peningkatan skor kemampuan komunikasi interpersonal satu minggu setelah pelatihan berakhir dari kategori rendah 
menjadi tinggi. Hal ini dikarenakan, L tetap melakukan berbagai teknik AT untuk mengatasi setiap permasalahan dalam kehidupan sehari-harinya walaupun pelatihan telah berakhir. Selama menjalani pelatihan, L menunjukkan motivasi dan rasa ingin tahu yang besar dalam mengikuti masing-masing sesi. Selain itu, L juga menunjukkan keinginan yang besar untuk mencoba hal-hal baru yang dipelajari selama proses pelatihan. L cukup kooperatif dan terbuka tehadap pengalamannya, hal ini terlihat dari keinginan L untuk selalu berusaha melaksanakan setiap instruksi yang diberikan pada saat pelatihan di masing-masing sesi pelatihan. Secara keseluruhan L melaksanakan pelatihan dengan antusias dan serius. Walaupun $\mathrm{L}$ terlihat tegang ketika hari pertama pelatihan dikarenakan ada beberapa pasien yang datang. Setelah melaksanakan pelatihan L mulai menyadari bahwa selama ini dirinya sangat tidak memahami dirinya, sehingga secara tidak sadar hal ini mengganggu kehidupannya sehari-hari.

Pada proses follow-up (setelah satu minggu setelah pelatihan), L menceritakan pengalamannya yang tetap rutin dalam melakukan kemampuan komunikasi interpersonal dalam kehidupan sehari-hari. L melakukan kemampuan AT ketika mengalami kondisi yang mengharuskan dirinya mengubah status ego baik di rumah maupun di tempat kerja. L paling sering menggunakan tekhnik refleksi diri karena paling banyak manfaat yang dirasakan L setelah menggunakannya yaitu merasa lebih dapat berpikir positif ketika menghadapi berbagai situasi dan kondisi. Serta lebih dapat memahami dan menghargai keadaan yang dirasakan.

Peserta Nomor 4 (NP)

Selama menjadi perawat NP merasa sangat menyukai pekerjaannya begitu juga ketika berhadapan dengan pasien dan dokter yang memiliki karakter berbeda setiap harinya. Meskipun begitu NP merasa terkadang dirinya merasa terbebani dengan permasalahan yang menumpuk dan harus diselesaikan dalam waktu yang cepat. NP sudah bekerja kurang lebih 4 tahun di bangsal dan 1 tahun di poli eksekutif Nusa Indah, selama itu pula NP merasa jarang mendapat masalah walaupun terkadang ketika memiliki masalah NP cenderung memilih untuk berdiam diri. Secara umum, NP tampak aktif dan antusias mengikuti pelatihan. NP aktif mengemukakan pendapatnya. Selain itu NP juga selalu melakukan pelatihan AT pada masing-masing teknik dirumah dan dalam kehidupan seharihari setiap sesinya. Skor kemampuan komunikasi interpersonal sebelum pelatihan adalah 57 dan setelah pelatihan 153, artinya NP mengalami peningkatan skor kemampuan komunikasi interpersonal sebesar 96 poin.

Pada follow-up yang dilakukan satu minggu setelah pelatihan, skor kemampuan komunikasi interpersonal meningkat menjadi 154 artinya ada peningkatan skor kemampuan komunikasi interpersonal satu minggu setelah pelatihan berakhir dari kategori rendah menjadi tinggi. Hal ini dikarenakan, NP tetap melakukan berbagai teknik AT untuk mengatasi setiap permasalahan dalam kehidupan sehari-harinya walaupun pelatihan telah berakhir. Selama menjalani pelatihan, NP 
menunjukkan motivasi dan rasa ingin tahu yang besar dalam mengikuti masing-masing sesi. Selain itu, NP juga menunjukkan keinginan yang besar untuk mencoba hal-hal yang baru dipelajari selama proses pelatihan. NP cukup kooperatif dan terbuka terhadap pengalamannya, hal ini terlihat dari keinginan NP untuk selalu berusaha melaksanakan setiap instruksi yang diberikan pada saat pelatihan di masing-masing sesi pelatihan. Secara keseluruhan NP melaksanakan pelatihan dengan antusias dan serius. Setelah melaksanakan pelatihan NP mulai menyadari bahwa selama ini dirinya sangat tidak memahami dirinya, sehingga NP mulai menggunakan teknik AT ketika menghadapi masalah.

Pada proses follow-up (setelah satu minggu setelah pelatihan), NP menceritakan pengalamannya yang tetap rutin dalam melakukan kemampuan komunikasi interpersonal dalam kehidupan sehari-hari. NP melakukan kemampuan AT ketika mengalami kondisi yang mengharuskan dirinya mengubah status ego baik di rumah maupun di tempat kerja. NP paling sering menggunakan tekhnik status ego karena paling banyak manfaat yang dirasakan NP setelah menggunakannya yaitu merasa lebih dapat mengendalikan ego dan lebih dapat berpikir positif ketika menghadapi berbagai situasi dan kondisi. Serta lebih dapat memahami dan menghargai permasalahan yang sedang dihadapi.

\section{Peserta Nomor $5(R)$}

R sudah bekerja kurang lebih 3 bulan di poli eksekutif Nusa Indah. Selama menjadi perawat $\mathrm{R}$ sangat menyukai pekerjaannya.
Meskipun terkadang $\mathrm{R}$ merasa bingung akan kesulitan dalam pekerjaannya. Hal ini terungkap pada saat sharing awal pelatihan. Secara umum, $\mathrm{R}$ tampak aktif dan antusias mengikuti pelatihan. $\mathrm{R}$ terbilang aktif mengemukakan pendapatnya. Selain itu R juga selalu melakukan pelatihan AT pada masingmasing teknik dirumah dan dalam kehidupan sehari-hari setiap sesinya. Skor kemampuan komunikasi interpersonal sebelum pelatihan adalah 80 dan setelah pelatihan 127 , artinya $\mathrm{R}$ mengalami peningkatan skor kemampuan komunikasi interpersonal sebesar 47 poin.

Pada follow-up yang dilakukan satu minggu setelah pelatihan, skor kemampuan komunikasi interpersonal tidak berubah yakni 127 artinya ada peningkatan skor kemampuan komunikasi interpersonal setelah pelatihan berakhir dari kategori rendah menjadi tinggi. Hal ini dikarenakan, $\mathrm{R}$ tetap konsisten melakukan berbagai teknik AT untuk mengatasi setiap permasalahan dalam kehidupan sehari-harinya walaupun pelatihan telah berakhir. Selama menjalani pelatihan, $\mathrm{R}$ menunjukkan motivasi dan rasa ingin tahu yang cukup besar salam mengikuti masingmasing sesi, selain itu $\mathrm{R}$ juga menunjukkan keninginan yang besar untuk mencoba hal-hal yang baru yang dipelajari selama proses pelataihan. $\mathrm{R}$ cukup kooperatif dan terbuka terhadap pengalamannya, hal ini terlihat dari keinginan $\mathrm{R}$ untuk selalu berusaha melaksanakan setiap instruksi yang diberikan pada saat pelatihan di masing-masing sesi pelatihan. Secara keseluruhan R melaksanakan pelatihan dengan antusias dan serius. Setelah melaksanakan pelatihan $\mathrm{R}$ mulai menyadari 
bahwa selama ini dirinya sangat tidak memahami dirinya, sehingga secara tidak sadar hal ini mengganggu kehidupannya sehari-hari.

Pada proses follow-up (setelah satu minggu setelah pelatihan), $\mathrm{R}$ menceritakan pengalamannya yang tetap rutin dalam melakukan kemampuan komunikasi interpersonal dalam kehidupan sehari-hari. $\mathrm{R}$ melakukan kemampuan AT ketika mengalami kondisi yang mengharuskan dirinya mengubah status ego baik di rumah maupun di tempat kerja. $\mathrm{R}$ paling sering menggunakan tekhnik Aku OK Kamu OK karena paling banyak manfaat yang dirasakan $\mathrm{R}$ setelah menggunakannya yaitu merasa lebih dapat mengendalikan diri agar lebih nyaman dalam bekerja dan lebih dapat berpikir positif ketika menghadapi berbagai situasi dan kondisi. Serta lebih dapat memahami dan menghargai diri sendir serta orang lain.

\section{Pembahasan}

Hasil penelitian menunjukkan bahwa terdapat perbedaan signifikan skor kemampuan komunikasi interpersonal partisipan antara kelompok eksperimen dan kelompok kontrol. Hipotesis penelitian terbukti yakni ada perbedaan skor pelatihan yang diberikan pada kelompok eksperimen dan kelompok kontrol yang tidak diberikan pelatihan AT. Berdasarkan hasil ini dapat disimpulkan bahwa pelatihan AT efektif meningkatkan kemampuan komunikasi interpersonal pada perawat dengan nilai $\mathrm{Z}=$ 2,032 ( $<<0,01)$. Hasil ini juga didukung oleh data kualitatif yang menunjukkan bahwa secara umum partisipan dalam pelatihan ini melaporkan adanya perubahan yang dirasakan setelah mengikutui pelatihan, diantaranya merasa lebih mengerti diri tentang diri lebih dalam, lebih mengenal tentang kepribadian diri sendiri, dan menambah pengetahuan tentang status ego yang harus digunakan dalam kehidupan sehari-hari. Keberhasilan pelatihan yang telah dicapai dalam penelitian ini mendukung beberapa penelitian tentang efektivitas pelatihan AT dalam meningkatkan kemampuan komunikasi interpersonal perawat. Penelitian tersebut antara lain, dilakukan oleh Mawikere (2012) dengan kesimpulan bahwa pelatihan AT dapat meningkatkan coping adaptif pada perawat. Partisipan dalam penelitian ini menunjukkan pemahaman mengenai cara-cara menujukkan ketegasan diri yaitu, menghindari ungkapan negatif terhadap orang lain, mengkaji sisi positif dari pengakuan negatif yang diberikan orang lain, serta mengendalikan respon status ego Adult kepada orang lain. Konfrontasi adaptif berwujud bentuk-bentuk perilaku asertif dan bukan berciri agresif, sehingga penggunaan status ego Adult harus mendominasi status ego Critical Parent dan status ego Child Adaptif (Boholst, 2002; DiMarco, 1979).

Modul pelatihan dalam penelitian ini disusun oleh Mawikere (2012) berdasarkan enam tekhnik pelatihan AT untuk meningkatkan kesejahteraan psikologis, yang meliputi Aku dan Kau harus OK, Analisis Struktural, Analisis Transaksi, Analisis Skrip dan Posisi Hidup, dan Simulasi. Keenam teknik tersebut, apabila diintegrasikan dan 
dilatihkan, akan mendukung terjadinya peningkatan kemampuan komunikasi interpersonal pada perawat.

Teknik pertama Aku dan Kau Harus OK bertujuan untuk membantu perawat mempersiapkan diri untuk mempelajari sesuatu yang baru, mmebuka kesadaran dan konsentrasi mengikuti pelatihan dan membangun kerjasama diantara sesama perawat, dokter dan pasien yang ada di poli eksekutif Nusa Indah. Pada teknik pertama ini partisipan tidak merasa kesulitan karena bagi mereka teknik ini dapat membantu partisipanpartispan untuk mempersiapkan diri mereka dalam menghadapi setiap permasalahan yang ditemui. $\mathrm{R}$ terkadang merasa tidak Ok ketika memberikan asistensi pada dokter kulit karena ia merasa tidak memahami apa yang diinginkan dokter terhadap dirinya. Hal ini diperkuat dengan pendapat (Coffield, dkk, 2004), dalam proses belajar di pelatihan AT pengamatan reflektif (melihat) yakni mengamati sebelum membuat penilaian dengan melihat lingkungan dari perspektif yang berbeda. Hal ini dapat memudahkan subjek dalam memahami maksud dari perintah atau instruksi yang diberikan padanya baik itu dari doker, pasien, kepala perawat maupun rekan sesama perawat.

Teknik kedua Analisis Struktural mengenalkan kepada partisipan mengenai konsep, mendiagnosa, kontaminasi, mendemonstrasikan dan ciri status ego serta agar partisipan memahami istilah stroke, jenisjenis, bentuk perhatian, pengakuan, ktitik strok dan mendemonstrasikan strok. Dalam tahap ini partisipan tidak mengalami kendala dalam mengikuti pelatihan AT. Hal ini sejalan menurut pandangan Stewart (Spanceley, 2009), AT berbeda dengan sebagian besar model terapi lain karena merupakan bentuk terapi berdasarkan kontraktual dan desisional. Analisis transaksional melibatkan suatu kontrak yang dibuat oleh klien, yang dengan jelas menyatakan tujuan-tujuan dan arah proses pelatihan. Analisis transaksional juga berfokus pada putusan-putusan awal yang dibuat oleh klien dan menekankan pada aspekaspek kognitif rasional-behavioral serta berorientasi pada peningkatan kesadaran, sehingga klien akan mampu membuat putusanputusan baru untuk mengubah cara hidupnya.

Teknik ketiga Analisis Transaksi memberikan gambaran awal pada perawat tentang transaksi dan interaksi, mengenalkan partsipan pada bentuk dan ciri transaksi sejajar, transaksi silang, transaksi sembunyi serta mengubah teknik transaksi yang kaku agar efektif. Pada tahap ini NP merasa dirinya kurang memahami dirinya sehingga terkadang merasa cemas serta khawatir terutama ketika harus menggunakan transaksi yang tepat untuk kondisi dan situasi dirinya saat ini. Hal ini terkait dengan pandangan Spanceley (2009), metode analisis transaksional merupakan bentuk penanganan masalah-masalah psikologis yang didasarkan atas hubungan antara klien dan terapis demi mencapai pertumbuhan kesejahteraan diri. Kesejahteraan diri dimaksud meliputi: terbebas dari keadaan tertekan, gangguan alam perasaan, kecemasan, berbagai gangguan perilaku khas serta masalah-masalah ketika membangun hubungan dengan orang lain. 
Teknik keempat Skrip dan Posisi Hidup membantu partisipan menelusuri hambatan kehidupan yang kurang disadari dan menyadarkan partisipan tentang pengaruh masa lalu yang mebatasi kehidupan saat ini dan memperkenalkan partisipan pada beberapa sikap posisi dan memberikan pilihan pada partisipan tentang posisi "Aku OK-Kamu OK”. L terkadang merasa dirinya selalu diatas karena posisinya perawat yang paling senior dan lama bekerja di poli eksekutif Nusa Indah. Hal ini membuat dirinya merasa terkadang semua orang disekitarnya harus mendengarkan apa yang dirinya inginkan dan pikirkan. Oleh karena itu L harus bisa meletakkan posisi dirinya sesuai dengan keadaan dan kondisi bukan berdasarkan apa yang diinginkan saat ini. Karena analisis transaksional (AT) berakar pada sebuah filsafat antideterminis bahwa manusia sanggup melampaui pengondisian dan pemrogaman awal. Disamping itu, analisis transaksional berpijak pada asumsi-asumsi bahwa setiap orang sanggup memahami putusan-putusan masa lampaunya dan bahwa mereka pun mampu memilih untuk kemudian memutuskan kembali setiap keputusan yang telah dibuat sebelumnya (Covey, 2005). Dengan demikian analisis transaksional meletakkan kepercayaan pada kesadaran dan kesanggupan individu.

Teknik kelima Stimulasi membantu perawat dalam mendemontransikan pola penganiaya, penolong dan korban dalam menggunakan kemampuan AT untuk meningkatkan kemampuan komunikasi interpersonal. Dalam teknik kelima ini $\mathrm{C}$ merasa dirinya kurang percaya diri padahal sebenarnya $\mathrm{C}$ merasa mampu dalam mengaplikasikan kemampuan yang ia miliki. Terutama ketika dirinya menghadapi pasien yang banyak maunya. Hal ini sependapat dengan Berne sebagai pendiri dan pengembang AT, Berne (Spanceley, 2009) memiliki pandangan optimis tentang hakikat individu, yaitu individu adalah makhluk yang memunyai kemampuan untuk hidup sendiri. Individu memiliki potensi untuk mengelola dirinya, termasuk mengatasi masalah-masalah yang dihadapinya, sehingga menjadi pribadi yang otonom dan mandiri, terlepas dari ketergantungan terhadap orang lain.

Individu adalah makhluk yang memiliki potensi untuk membuat keputusan. Individu memunyai kemampuan untuk membuat rencana-rencana kehidupan, kemudian memilih dan memutuskan rencana-rencana terbaik bagi dirinya. Rencana-rencana yang telah dibuatnya itu terus dinilai sesuai dengan irama perkembangan hidupnya, sehingga ia dapat memutuskan rencana yang lebih baik lagi bagi kehidupan selanjutnya. Individu adalah makhluk yang bertanggung jawab. Individu bukan hanya mampu hidup mandiri dan membuat keputusan untuk dirinya, namun ia juga mampu bertanggung jawab atas pilihan dan putusan yang diambilnya serta konsekuensi yang akan ditimbulkannya. Pandangan ini sangat memengaruhi usahausaha bantuan terapi terhadap pasien. Dalam hal ini hubungan $\mathrm{C}$ sebagai perawat dengan pasien, maka ciri hubungan idealnya adalah transaksi sejajar (compliment) dalam proses terapis dan keduanya harus sama-sama berbagi 
tanggung jawab dalam penetapan dan pencapaian tujuan terapi.

Pada follow-up yang dilakukan satu minggu setelah pelatihan berakhir, secara umum skor kemampuan komunikasi interpersonal peserta mengalami peningkatan. Hal ini dikarenakan peserta tetap mempraktekkan kemampuan komunikasi interpersonal dalam kehidupan sehari-hari. Seperti diungkapkan partisipan bahwa dipraktik AT dalam kehidupan sehari-hari terutama ketika menghadapi situasi dan kondisi yang membuat peserta harus memposisikan dirinya menurut status ego masing-masing.

Ekman (2003) menegaskan bahwa emosi dapat mengubah cara pandang seseorang terhadap dunia dan bagaimana menafsirkan tindakan orang lain. Hambatan inisiatif untuk mengerti secara logis mengapa sesuatu bisa terjadi dan keterbatasan derajad evaluatif akan mengabaikan potensi pengetahuan yang dimiliki, akibatnya menghambat alur pemrosesan informasi baru yang mungkin dapat dijadikan sebagai strategi penyelesaian masalah.

Hasil penilaian positif, netral atau negatif akan bergantung pada kapsitas kognitif perawat dan kapasitas kognitif ini dalam analisis transaksional lebih merupakan kekuatan status ego Adult sebagai pengontrol (Bennets \& Rob, 2008; Levin, 2003), ketrampilan transaksi analisis dan posisi hidup bila berhubungan dengan orang lain baik itu sesama perawat, dokter maupun pasien. Dalam hal ini belajar untuk berpikir posistif dengan orang yang menjengkelkan.
Selain faktor teknik AT yang digunakan, faktor lain yang juga mendukung keberhasilan pelatihan yaitu kesadaran partisipan pelatihan yang terlibat dalam pelatihan. Hasil analisis kualitatif menunjukkan bahwa partisipan yang mengalami peningkatan skor kemampuan komunikasi interpersonal yang tinggi, didukung oleh adanya motivasi yang tinggi dalam mengikuti semua proses pelatihan, sikap terbuka untuk menceritakan pengalaman dan perasaannya selama mengikuti pelatihan dan berusaha melaksanakan dan menerapkan kemampuan AT yang diberikan dalam kehidupan sehari-hari. Hal ini sesuai dengan komponen utama yang harus dipenuhi dalam proses AT yaitu experiental learning, dimana partisipan akan dikondisikan agar memenuhi langkah-langkah proses belajar dengan melihat, berpikir dan melakukan, pengalaman saat ini atau fokus pada peristiwa sekarang serta penerimaan (Coffield, 2005). Selain itu, kesadaran partisipan ini tetap terjaga walaupun proses pelatihan sudah berakhir. Partisipan tetap melakukan dan menerapkan kemampuan AT dalam kehidupan sehari-hari sehingga pada pengukuran follow-up, kemampuan komunikasi interpersonal cenderung meningkat walaupun ada beberapa yang tidak mengalami peningkatan dikarenakan faktor lain yang terjadi pada partisipan diluar kendali peneliti. Selain itu, partisipan yang mengalami peningkatan skor kemampuan komunikasi interpersonal yang sedikit, disebabkan karena kurang terpenuhinya komponan utama dalam proses AT, meskipun menunjukkan sikap antusias dan berusaha mengikuti pelatihan 
dengan baik, namun masih kesulitan untuk fokus pada keadaan saat ini, serta belum cukup terbuka untuk menerima dan melepaskan perasaan yang dimiliki.

\section{KESIMPULAN}

Hasil penelitian menunjukkan bahwa pelatihan AT dapat meningkatkan kemampuan komunikasi interpersonal dengan nilai uji $\mathrm{Z}$ sebesar -2,032 $(\mathrm{p}<0,01)$ dengan rata-rata kenaikan skor sebesar 69,4 dan skor kemampuan komunikasi interpersonal dapat meningkat dan tetap bertahan meskipun pelatihan AT telah selesai dilaksanakan. Selain meningkatkan skor kemampuan komunikasi interpersonal, pelatihan AT juga merupakan metode yang berorientasi pada menelusuri pengalaman-pengalaman menyedihkan sebagai manifestasi dari suatu kebuntuan, konflik intra psikis, dan atau hambatan interpersonal terutama menyangkut pola komunikasi dari masing-masing pihak ketika berinteraksi, juga merupakan petunjuk arahan mengenai cara berespon saat berada dalam situasi yang menekan atau mengancam diri. Dengan analisis transaksional perawat bisa belajar mempercayai dirinya sendiri, berpikir, dan memutuskan untuk dirinya sendiri, serta mampu mengendalikan perasaan dan emosinya. Kondisi emosi yang berbeda akan menciptakan gaya informasi pengolahan yang berbeda serta suasana emosi akan berdampak kondusif terhadap kreatifitas, intuitif, dan ekspansif untuk menciptakan asosiasi-asosiasi baru. Perawat yang dapat menggunakan metode analisis transaksional untuk meningkatkan ketrampilan mengatasi ataupun mengendalikan bentuk-bentuk permasalahan yang dihadapi akan meningkatakan kualitas pribadi perawat serta mampu menghadapi situasi sulit.

Manfaat pelatihan AT akan lebih optimal sejauh pelaksanaannya tetap memakai prinsip-prinsip AT yaitu experiental learning, pengalaman belajar dengan melihat, berpikir dan melakukan saat ini atau fokus pada keadaan dan kondisi saat ini, serta penerimaan dan dilaksanakannya pelatihan AT dalam kehidupan sehari-hari. Berdasarkan hasil penelitian, peneliti menyampaikan beberapa saran sebagai berikut :

1. Kepada Kalangan Profesional

a. Hasil penelitian yang menunjukkan bahwa pelatihan AT dapat meningkatkan kemampuan komunikasi interpersonal perawat, diharapkan dapat menambah wawasan keilmuan psikologi serta dijadikan acuan dan program alternatif dalam upaya peningkatan manajemen mutu pelayanan keperawatan.

b. Pelatihan AT dapat digunakan sebagai salah satu program untuk meningkatkan kemampuan komunikasi interpersonal perawat dan dilaksanakan secara periodik dan berkesinambungan.

2. Kepada Peneliti Selanjutnya

a. Perlunya pengaturan jadwal pelatihan agar lebih mempertimbangkan kesempatan dan keleluasaan partisipan dalam melakukan latihan secara mandiri. 
b. Waktu pelaksanaan pelatihan perlu disesuaikan dengan jadwal kerja partisipan, sehingga faktor kelelahan setelah bekerja yang dapat mengganggu konsntrasi partisipan menjalani pelatihan dapat dihindari.

c. Pada pelatihan ini tidak didesain dengan pengontrolan tugas rumah, sehingga memengaruhi beberapa hasil follow-up yang kurang baik. Pengontrolan tugas rumah ini dapat dilakukan dengan pihak keluarga atau orang terdekat lainnya, sehingga apa yang telah dilakukan dalam pelatihan dapat diterapkan dirumah dan dalam kehidupan sehari-hari.

d. Peneliti selanjutnya dapat menggunakan AT sebagai metode pelatihan atau intervensi bagi permasalahan psikologis lainnya.

e. Penelitian sejenisnya sebaiknya juga dilakukan pada Rumah Sakit lain yang berbeda jenis dengan yang peneliti lakukan, karena penelitian dengan tipe Rumah Sakit yang berbeda belum tentu akan memperoleh hasil yang sama.

\section{DAFTAR PUSTAKA}

Azwar, S. (2005). Dasar-dasar psikometri cetakan kelima. Yogyakarta : Pustaka Pelajar.

Bagus, S.B. (2009) Uji validitas skala egogram dan keefektifan analisis transaksional untuk menurunkan tekanan darah pasien hipertensi di poliklinik CV. RSM Grup. Digital Library Universitas Sebelas Maret. Diunduh 13/01/2015.
Corey, G. (2005). Theory and practice of counseling and psychotherapy. Seventh edition. Belmount : Brooks/ColeThomson Learning.

Durand, V.M. \& Barlow, D.H. 2006. Intisari Psikologi Abnormal. Yogyakarta : Pustaka Belajar.

Dussay, J.M., Dussheapk9ay, C., \& Mulholland (1984) Transactional Analysis In Corsini Raymond J., (1984) Current Psychotherapies . Third Ed,F.E. Peacock Publisher.Inc.

Effendi, O.U, (1983) Psikologi manajemen, Jakarta : Penerbit Alumni.

Egan, G. (2010). The Skilled Helper a Problem-Management and OpportunityDevelopment Approach to Helping. Ninth Edition. Belmont, CA : Brooks/Cole

Florio, G.A., Donnely, J.P.,\& Zevon, M.A. (1998). The structure of work-related stress and coping among ancology nurses in high-stress medical settings: a transactional analysis. Journal of Occupational Health Psychology, 3(3), 227-242.

Graham, M. (2009) The Roots of Emotional Eating : transactional analysis. http://soc.cahs.colostatc.cdu/Graduatc/ Med/CCD/Talk/Dcfault.aspx diunduh 12/07/2015 01.40 wib.

Greenberg, L.E. (2002) Emotion-Focused therapy : coaching clients to work throught their feelings. Washington, DC. American Psychological Assosiation.

Handayani, M.M., Ratnawaty, S. \& Helmi , A.F. (1998) Efektivitas pelatihan pengenalan diri terhadap peningkatan penerimaan diri danharga diri. Jurnal Pikologi, Nomor .2, 47-45.

Harris, T (1992) Saya oke kamu oke. Jakarta : Cipta Loka Caraka.

Hardjana, A.M. 2003. Komunikasi Intrapersonal \& Interpersonal. Yogyakarta: Kanisius. 
Harrop, E., Eddis, S., Elliott E., \& Williams, G. (2006) Resilience, coping and salutogenic approaches to maintaining and generating health : review. Cardiff Institute of Society, health and ethics. BC 3-2.

Joines, V.. ( 2005) Transactional analysis : helping our clients achieve a sense of okay-ness. Research design in clinical psychology. Massachusets, USA : Allyn \& Bacon/ http://www.ta-psychotherapy. Co.uk/psychotherapy.htm diunduh 12/07/2015 01.40 wib.

Kececia, A., * Tasocakb, G (2009) Nurse faculty members' ego states : transactional analysis approach. Nurse Education Today 29-7, 746-752.

Kementrian Kesehatan RI. (2001) Keputusan Menteri Kesehatan Nomor 1239/MenKes/SK/XI/2001 tentang Registrasi dan Praktik Perawat. Jakarta.

Latipun, F. (2006). Psikologi Eksperimen. Malang : Universitas Muhammadiyah Malang.

Levin,P. (2003) Games Nurses Play. American Journal of Noursing. 72 (3) 56-67.

Liliweri, A. 1991. Komunikasi antar pribadi. Bandung : Penerbit Erlangga.

Martin, G.,\& Pear, J. (2003) Behavior modification what it is and how to do it. New Jersey: Pearson Education, Inc.

Mawikere, J. (2012). Efektivitas pelatihan Analisis Transaksional untuk Peningkatan Koping Adaptif pada Perawat di RSU RDK Manado. Tesis (tidak diterbitkan). Yogyakarta : Fakultas Psikologi Universitas Mercu Buana Yogyakarta

Mulyana, D. 2007. Ilmu Komunikasi. Bandung: Penerbit Erlangga.

Purwadarminta, W.J.S. 2003. Kamus Umum Bahasa Indonesia. Jakarta : Balai Pustaka.

Purwandari, 2007. Gaya kelekatan aman dan komunikasi efektif antara remaja awal dan ibu. Skripsi. (tidak diterbitkan).
Yogyakarta : Fakultas Psikologi Warsa Manggala.

Parissopoulos, S., \& Kotzabassaki, S (2004) Orem's Self-care Theory, transactional analysis and the management of elderly rehabilitations. JCUS NURS WEB J. Issue 17, 1-11.

Rakhmat, J. 2007. Psikologi Komunikasi (Edisi Revisi). Bandung : Remaja Rosdakarya.

Rusmana, A. 2008. Komunikasi efektif Dokter Gigi-Pasien.

http://www.sribd.com/doc/39988.

Diakses 6 Juni 2015.

Salomon, C. (2003) Transactional analysis : the basic. Transactional Analysis Journal. 33. (1) 15-22.

Santrock, J.W. (2012). Life-span development : Perkembangan masa hidup edisi ketigabelas jilid 2. Jakarta : Erlangga.

Sekretaris Negara 91996) Peraturan pemerintah Nomor 32 Tahun 1996 tentang Tenaga Kesehatan. Jakarta.

Schmid, B. (2008) The role concept of transactional analysis and other approach to personality, encounter, and cocreativity for all professional fields. Transactional Analysis Journal. 38, (1) 17-30.

Sloman, M. (2009) Training and it's significance in the workplace. Mental capital and wellbeing: making the most of ourselves in the 21st century. Stateof-Science Review: SR-C9 www.foresight.gov.ukdiunduh 12/07/2015 01.40 wib.

Spanceley, D. (2009) An introduction to transactional analysis and transactional analysis bief therapy : teaching and supervising transactional analysis UKCP registered TA psychoterapist. http://www.ta-psychotherapy.co.uk diunduh 12/07/201501.40 wib.

Steiner, C. M. (2002) The adult : Once again with feeling. Transactional Analysis Journal. 1-32. 
Stewart, I (1996) Developing transactional analysis counselling. London : Sage Publication.

Spacapan, S \& Oskamp.S.1994. The Social Pshychology of Health. California : Sage Publications.

Suprapto, T. 2008. Teknik Jitu Persuasi dan Negosiasi : Resep Bagaimana Melakukan Negosiasi dengan Memanfaatkan Konsep-Konsep Dasar Komunikasi Efektif. Yogyakarta : Media Presindo.

Symister, P. \& Friend, R. 2003. The influence of social support and problematic support on optimism and depresion in chronic illness : a prospective study evaluating self-esteem as a mediator. American Phsycological Association. Journal of Health Psychology.Vol.22(2), hal 123-129.

Tubbs, S.L \& Moss, S.1996. Human Communication, Bandung Remaja Rosdakara.

Walgito, B. 2002. Psikologi Umum. Yogyakarta : Andi.

Walgito, B.2003. Psikologi sosial (Suatu Pengantar). Yogyakarta : Andi. 